\title{
SISTEM MONITORING DAN CONTROLLING PASIEN TUBERKULOSIS (TB) BERBASIS WEB INTERAKTIF
}

\author{
${ }^{1,2}$ Herika Hayurani, ${ }^{1}$ Fenny Desri Hartanti \\ ${ }^{1}$ Program Studi Teknik Informatika, Fakultas Teknologi Informasi, Universitas YARSI, Jakarta, Indonesia \\ ${ }^{2}$ YARSI E-Health Research Center (YEHRC) \\ E-mail: herika.hayurani@yarsi.ac.id
}

\begin{abstract}
Tuberculosis (TB) is a disease caused by Mycobacterium tuberculosis bacteria. The aims of this research are to develop a web-based application that can facilitate TB Care personnel to manage and visualize the data of patients and cadres. TB care is a community-based organization to prevent TB in Indonesia. The prevention and treatment of $T B$ can be achieved with the cooperation of society. In order to ensure the achievement of the objectives, so the participation of cadre is expected. Cadre is a member of the community who volunteered to assist the TB control program and have been trained to look into an environment that has symptoms of TB. This research is a participation that takes a part in dealing with TB disease control. This research was conducted using methodology that consists of literature study, identification of needs, system design, system implementation, and system testing. This research produces a system that tested to user using User Experience Questionnaire (UEQ) analysis. UEQ is a testing method using a questionnaire that has six categories: attractiveness, efficiency, perspicuity, dependability, stimulation, and novelty. The UEQ analysis shows that the system achieves an excellent average of these six categories.
\end{abstract}

Keywords: Tuberculosis, monitoring and controlling TB system, User Experience Questionnaire

\begin{abstract}
Abstrak
Tuberkulosis (TB) adalah suatu penyakit yang disebabkan oleh bakteri Mycobacterium tuberculosis. Penelitian ini bertujuan untuk membangun sebuah aplikasi berbasis web yang dapat memudahkan petugas TB Care dalam mengelola serta memvisualisasikan data pasien dan kader. TB Care merupakan suatu lembaga berbasis komunitas dalam penanggulangan TB di Indonesia. Pencegahan dan pengobatan TB bisa tercapai dengan kerjasama berbagai pihak dalam masyarakat. Untuk memastikan tercapainya tujuan tersebut, maka diharapkan adanya kader kesehatan. Kader merupakan anggota masyarakat yang bekerja sukarela dalam membantu program penanggulangan TB dan sudah dilatih untuk mencari suspek TB. Penelitian ini merupakan suatu bentuk partisipasi turut serta dalam menangani pengendalian penyakit TB. Penelitian ini dilakukan dengan metodologi pengembangan perangkat lunak, yang terdiri dari tahap studi literatur, identifikasi kebutuhan, desain sistem, implementasi sistem, dan pengujian sistem. Penelitian ini menghasilkan sistem yang kemudian diuji menggunakan analisis User Experience Questionaire (UEQ). UEQ merupakan sebuah metode pengujian dengan menggunakan kuesioner yang memiliki enam kategori yaitu daya tarik, efisiensi, kejelasan, ketepatan, stimulasi, dan kebaruan. Berdasarkan hasil pengujian, sistem ini mendapatkan nilai rata-rata sangat baik dari setiap kategori dalam analisis UEQ.
\end{abstract}

Kata Kunci: Tuberkulosis, sistem monitoring dan controlling TB, User Experience Questionnaire 


\section{Pendahuluan}

Tuberkulosis (TB) merupakan suatu penyakit menular yang disebabkan oleh kuman Mycobacterium Tuberculosis yang dapat menginfeksi paru dan organ tubuh lainnya seperti kelenjar, kulit, tulang, dan otak. Bakteri ini merupakan bakteri basil yang sangat kuat sehingga memerlukan waktu lama untuk mengobatinya (Harjana 2013). Penyakit TB merupakan masalah kesehatan, baik dari sisi angka kematian (mortalitas), angka kejadian penyakit (morbiditas) maupun diagnosis. Telah ada riset yang menyatakan bahwa, pada tahun 2015, Indonesia menduduki peringkat kedua dengan negara-negara yang memiliki penderita TB terbesar di dunia (World Health Organization 2015).

Beberapa faktor penyebab meningkatnya masalah TB yaitu tingginya angka kemiskinan dengan kondisi sanitasi, papan, sandang yang buruk, tingginya angka pengangguran, rendahnya tingkat pendidikan masyarakat, tidak disiplinnya penderita TB dalam menelan obat. Program pengendalian TB Nasional (2014) masih mengalami masalah antara lain: belum seluruhnya fasilitas pelayanan kesehatan terlibat sepenuhnya dalam program pengendalian $\mathrm{TB}$, kurang dari $30 \%$ tenaga staf TB di rumah sakit yang sudah terlatih, belum optimalnya sistem manajemen Obat Anti Tuberkulosis (OAT), dan rendahnya alokasi APBD untuk pengendalian TB (Kemenkes RI 2014). Faktor-faktor tersebut dapat mempengaruhi tingginya angka kesakitan dan angka kematian penderita TB.

TB dapat disembuhkan apabila pasien rutin berobat selama enam bulan tanpa putus. Keluarga pasien harus mendukung pasien selama pengobatan TB tersebut. Dukungan psikososial terhadap penderita TB merupakan komponen penting dalam tata laksana efek samping obat TB (Asri 2014). Pengawas Menelan Obat (PMO) berperan untuk memberikan edukasi dan semangat kepada pasien untuk terus melanjutkan pengobatan. Pertemuan kelompok pendukung juga dapat menjadi bentuk dukungan psikososial bagi pasien.

Salah satu strategi nasional pengendalian TB di Indonesia 2010-2014 (Kemenkes RI 2011) adalah melibatkan seluruh penyedia pelayanan pemerintah, masyarakat (sukarela), perusahaan dan swasta melalui pendekatan Pelayanan TB Terpadu Pemerintah dan Swasta (Public-Private Mix) dan menjamin kepatuhan terhadap Standar Internasional Penatalaksanaan TB (International Standards for TB Care). Universitas YARSI adalah institusi pendidikan tinggi yang melaksanakan program "Community TB Care" untuk mendukung Strategi Nasional Pengendalian TB di Indonesia. TB Care merupakan suatu lembaga berbasis komunitas dalam penanggulangan TB di Indonesia. Pencegahan dan pengobatan TB bisa tercapai dengan kerjasama berbagai pihak dalam masyarakat. Untuk memastikan tercapainya tujuan tersebut maka TB Care merekrut kader TB. Kader TB merupakan anggota masyarakat yang bekerja sukarela dalam membantu program penanggulangan TB dan sudah dilatih untuk mencari di lingkungan yang memiliki gejala TB.

Pada tanggal 7 Oktober 2015 dilakukan wawancara kepada Dr. dr. H. Artha Budi Susila Duarsa, M.Kes selaku Ketua YARSI TB Care, serta Zulfha Nurlia, Edi Winarko, dan Randi Ikwan selaku petugas YARSI TB Care. Berdasarkan hasil wawancara tersebut, diperoleh informasi bahwa pengolahan laporan di TB Care masih dilakukan secara manual, artinya dari segi pencatatan masih menggunakan selembar kartu kontrol. Hal tersebut tidaklah efektif apabila mengolah data dengan jumlah data yang banyak menjadi sebuah bentuk laporan, karena memerlukan waktu, tenaga, dan ketelitian. Salah satu hal yang dapat dilakukan, yaitu dengan adanya pemanfaatan sistem sebagai media dalam mengatasi kendala tersebut.

Berdasarkan masalah yang telah diuraikan, maka penulis menyimpulkan bahwa perlu dilakukan sebuah penelitian berupa pembuatan sistem monitoring dan controlling pasien TB berbasis web interaktif. Sistem ini dapat digunakan untuk membantu petugas TB Care dalam memantau pengawasan pasien TB. Pembuatan sistem monitoring dan controlling pasien TB mampu menghasilkan informasi mengenai $\mathrm{TB}$, melihat penyebaran pasien dan fasilitas layanan kesehatan melalui peta lokasi, melihat grafik visualisasi penderita TB, serta pendataan lengkap seperti data kader dan data pasien.

\section{Metodologi}

Metodologi penelitian (Gambar 1) terdiri dari 5 (lima) tahapan yaitu studi literatur, identifikasi kebutuhan, desain, implementasi, dan pengujian. 


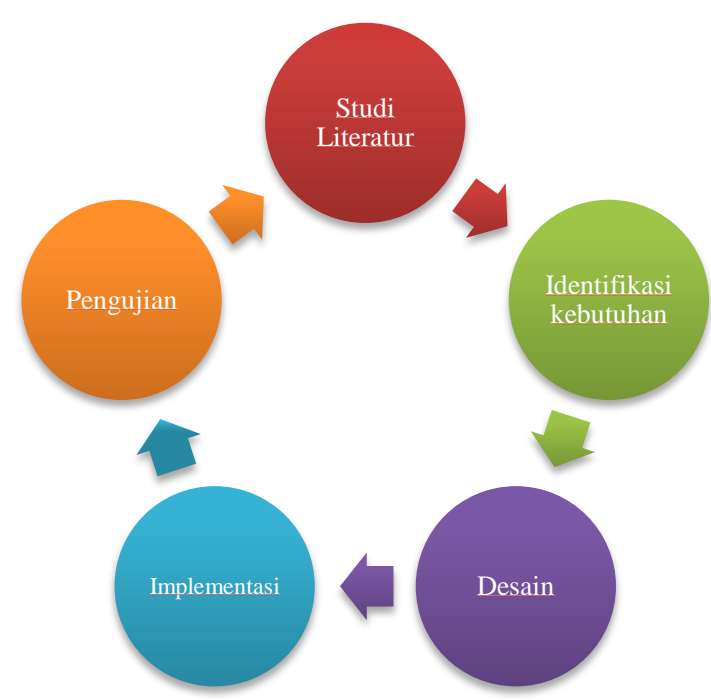

Gambar 1. Metodologi penelitian

\subsection{Studi Literatur}

Pada tahapan ini penulis melakukan pengkajian dan peninjauan beberapa sumber pustaka untuk mencari informasi yang berkaitan dengan obyek penelitian. Beberapa sumber pustaka yang dapat digunakan oleh peneliti diantaranya adalah buku referensi, paper, jurnal, dan beberapa artikel. Buku referensi yang penulis pelajari dalam penelitian ini berisikan tentang informasi mengenai penyakit TB, cara pengobatan pasien $\mathrm{TB}$, serta mengetahui lebih mendalam mengenai komponen-komponen teknologi yang dapat digunakan untuk membuat aplikasi berbasis web.

\subsection{Identifikasi Kebutuhan}

Pada tahap ini, penulis melakukan kegiatan untuk memenuhi kebutuhan pengguna terhadap aplikasi yang dikembangkan. Hal ini perlu dilakukan agar aplikasi yang dikembangkan sesuai dengan kebutuhan pengguna. Kegiatan yang dilakukan pada tahap ini penulis melakukan wawancara kepada beberapa stakeholder untuk memenuhi kebutuhan yang diperlukan sebagai bahan data dalam pembangunan sistem ini. Skenario yang dilakukan dalam proses wawancara ini adalah dengan menyiapkan beberapa pertanyaan untuk mengetahui kebutuhan pengguna, menyiapkan alat bantu wawancara seperti perekam suara dan mencatat semua hasil yang didapatkan.

Pada tahapan ini juga, penulis melakukan user requirement yang bertujuan untuk memahami kebutuhan dari sistem yang akan dibuat, baik untuk kebutuhan sistem maupun dilihat dari sesi pengguna. Dari hasil user requirement, pengguna sistem terdiri dari 2 (dua) jenis pengguna, yaitu administrator dan tamu. Kebutuhan sistem ini terdiri dari kebutuhan fungsional dan kebutuhan non fungsional. Tabel 1 memuat daftar kebutuhan fitur untuk administrator dan Tabel 2 memuat daftar kebutuhan fitur untuk tamu. Tabel 3 memuat daftar kebutuhan non fungsional sistem.

Tabel 1. Kebutuhan fungsional administrator

\begin{tabular}{|c|c|c|}
\hline No & Requirement & Preference \\
\hline 1 & Dapat melakukan login. & Mandatory \\
\hline 2 & $\begin{array}{l}\text { Dapat menambahkan informasi } \\
\text { seputar penyakit TB. }\end{array}$ & Mandatory \\
\hline 3 & $\begin{array}{l}\text { Dapat menambahkan, mengubah, dan } \\
\text { menghapus data kader. }\end{array}$ & Mandatory \\
\hline 4 & Dapat melihat data dan detail kader. & Mandatory \\
\hline 5 & $\begin{array}{l}\text { Dapat mengatur kader untuk pe- } \\
\text { ngawasan pasien. }\end{array}$ & Mandatory \\
\hline 6 & $\begin{array}{l}\text { Dapat mengubah pengaturan kader } \\
\text { untuk pengawasan pasien. }\end{array}$ & Mandatory \\
\hline 7 & Dapat melihat data pasien. & Mandatory \\
\hline 8 & $\begin{array}{l}\text { Dapat melihat kartu kontrol (rutinitas) } \\
\text { pasien. }\end{array}$ & Mandatory \\
\hline 9 & $\begin{array}{l}\text { Dapat memvisualisasikan grafik dari } \\
\text { data pasien menurut jenis kelamin, } \\
\text { tipe pasien, dan kecamatan/tempat } \\
\text { tinggal pasien. }\end{array}$ & Mandatory \\
\hline 10 & Dapat menambahkan admin baru. & Mandatory \\
\hline 11 & $\begin{array}{l}\text { Dapat memetakan lokasi pasien dan } \\
\text { fasilitas layanan kesehatan (fasyankes) } \\
\text { secara otomatis }\end{array}$ & Desirable \\
\hline
\end{tabular}

Tabel 2. Kebutuhan fungsional tamu

\begin{tabular}{clc}
\hline No & \multicolumn{1}{c}{ Requirement } & Preference \\
\hline 1 & $\begin{array}{l}\text { Dapat melihat informasi seputar TB } \\
\text { berdasarkan kategori }\end{array}$ & Mandatory \\
2 & $\begin{array}{l}\text { Dapat melihat penyebaran fasilitas } \\
\text { layanan kesehatan (fasyankes) }\end{array}$ & Mandatory \\
\hline
\end{tabular}

Tabel 3. Kebutuhan non fungsional

\begin{tabular}{|c|c|c|}
\hline No & Requirement & Preference \\
\hline 1 & Responsive & Mandatory \\
\hline 2 & User friendly & Mandatory \\
\hline 3 & Keamanan sistem baik & Desirable \\
\hline
\end{tabular}

\subsection{Desain}

Tahapan desain adalah tahapan membuat rancangan kebutuhan database yang diperlukan untuk memenuhi kebutuhan kepada pemakai sistem. Desain sistem 
mencakup model Entity Relationship Diagram (ERD), perancangan model Unified Modeling Language (UML) dengan menggunakan use case diagram dan bagan alir sistem (system flowchart).

\subsubsection{Desain Basis Data}

Desain basis data dalam sistem ini menggunakan model Entity Relationship Diagram (ERD) untuk menggambarkan kebutuhan informasi yang akan disimpan di dalam database. ERD ditunjukkan pada Gambar 2.

Berdasarkan Gambar 2, database sistem terdiri dari 11 tabel yaitu admin, kader, pasien, alamat, fasyankes, kartu kontrol, berita, kategori, last update berita, last update alamat, dan pengawasan pasien. Admin ditugaskan untuk mengelola berita, mengatur pasien, memasukkan alamat pasien, dan mengelola kader. Setiap berita yang dimasukkan memiliki kategori berita. Satu pasien memiliki kartu kontrol sebagai rutinitas pasien dalam menelan obat. Masing-masing kader dapat mengawasi satu atau lebih dari satu pasien. Setiap admin, kader, pasien, dan fasyankes memiliki alamat sebagai identitas masing-masing.

Terdapat tiga relasi many to many pada ERD, yaitu relasi antara admin dan pasien, admin dan berita, serta admin dan alamat. Oleh sebab itu, dibuat entitas baru di antara relasi many to many tersebut. Entitas pengawasan pasien dibuat akibat relasi many to many antara admin dan pasien. Entitas last update berita dibuat akibat relasi many to many antara admin dan berita. Entitas last update alamat dibuat akibat relasi many to many antara admin dan alamat.

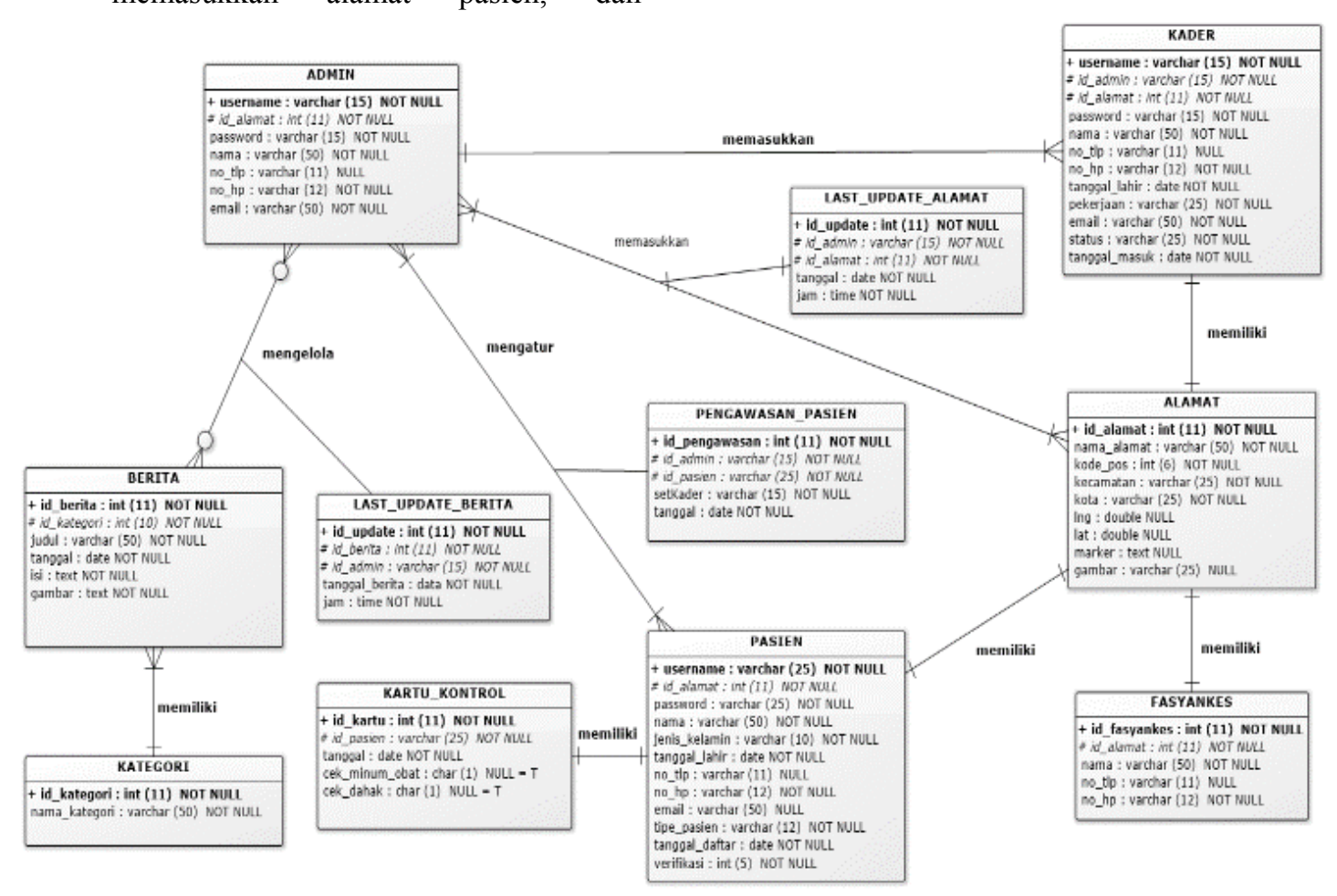

Gambar 2. ERD Sistem

\subsubsection{Desain Model}

Sistem monitoring dan controlling pasien TB ini merupakan sistem berbasis web yang dapat memudahkan setiap administrator dalam mendata setiap pasien TB. Sistem ini dikembangkan untuk dapat lebih cepat dipublikasikan melalui media online sehingga sistem dapat mempermudah tugas-tugas dan tanggung jawab bagian administrator.

Gambar 3 merupakan pemodelan use case diagram yang menunjukkan hal-hal apa saja yang dapat dilakukan oleh pengguna terhadap sistem. Sistem memiliki 2 (dua) level pengguna, yaitu administrator dan tamu. 
Level pengguna tamu memiliki hak akses terbatas hanya pada melihat penyebaran fasilitas pelayanan kesehatan (fasyankes), melihat informasi/berita terkait TB, melihat halaman Tentang Kami, dan melihat halaman Hubungi Kami.

Level administrator memiliki hak akses penuh terhadap sistem, yaitu semua hal yang dapat dilakukan oleh tamu, ditambah dengan hak akses khusus. Hak khusus administrator adalah mengelola penyebaran fasyankes, melihat penyebaran pasien TB, melihat grafik penderita TB berdasarkan jenis kelamin, tipe pasien, dan kecamatan, mengelola kader, mendaftarkan admin, melihat data pasien, melihat kartu kontrol sebagai rutinitas pengobatan pasien, dan mengelola berita mengenai TB. Hak khusus ini dapat dilakukan setelah administrator login ke dalam sistem.

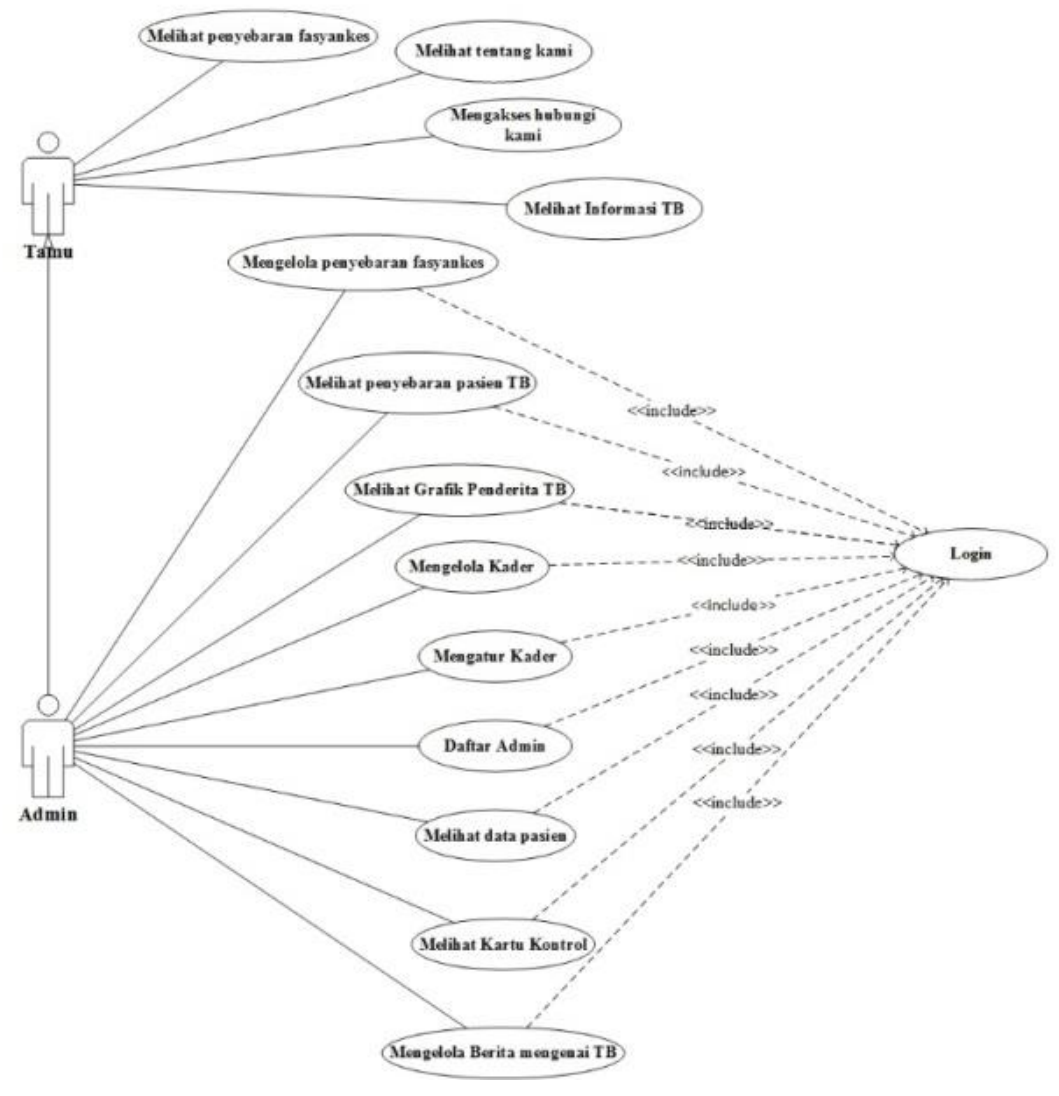

Gambar 3. Use case diagram sistem

\subsubsection{Desain Alur Sistem}

Flowchart pada Gambar 4 menunjukkan alur kerja sistem dalam melakukan input berita yang dimasukkan oleh admin. Gambar 5 merupakan bagan yang menunjukkan alur kerja dalam melakukan proses login admin pada sistem.

Gambar 6 menunjukkan alur proses untuk melakukan kelola kader. Saat user memilih menu kader, user dapat menambahkan kader baru dengan mengisi data dalam form yang telah disediakan pada sistem. Jika data yang dimasukkan sudah valid, sistem akan menampilkan pesan konfirmasi bahwa kader tersebut sudah disimpan di dalam database.

Selain menambahkan kader baru, user juga dapat mengubah data kader pada sistem dengan memilih nama kader yang akan diubah. Jika data yang dimasukkan sudah valid, sistem akan menampilkan pesan konfirmasi bahwa kader tersebut sudah diubah di dalam database. Adapun dalam menghapus data kader, user dapat memilih data kader yang akan dihapus di dalam sistem. 


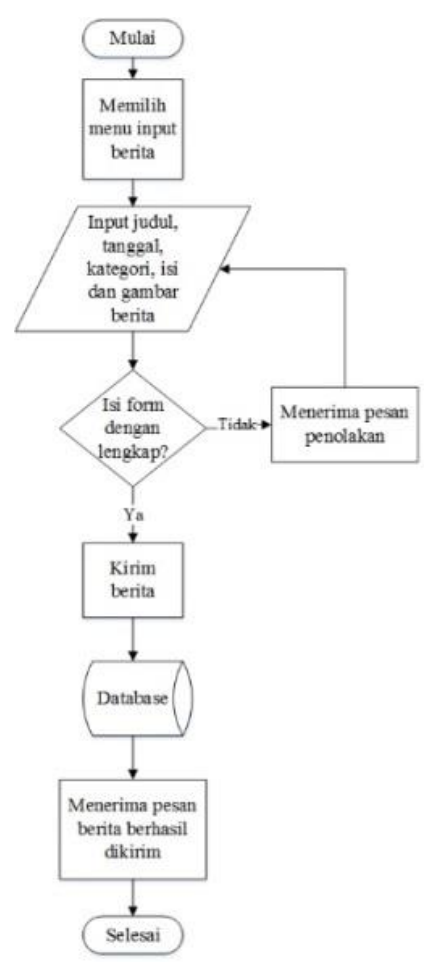

Gambar 4. Flowchart input berita

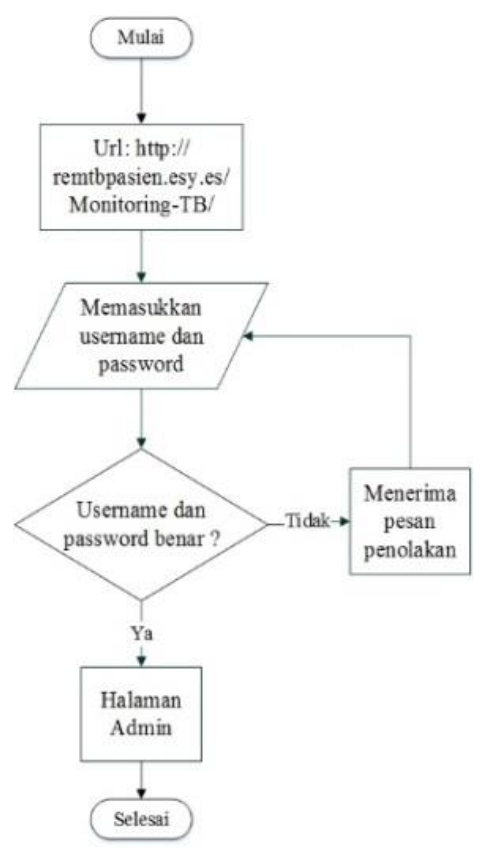

Gambar 5. Flowchart login administrator

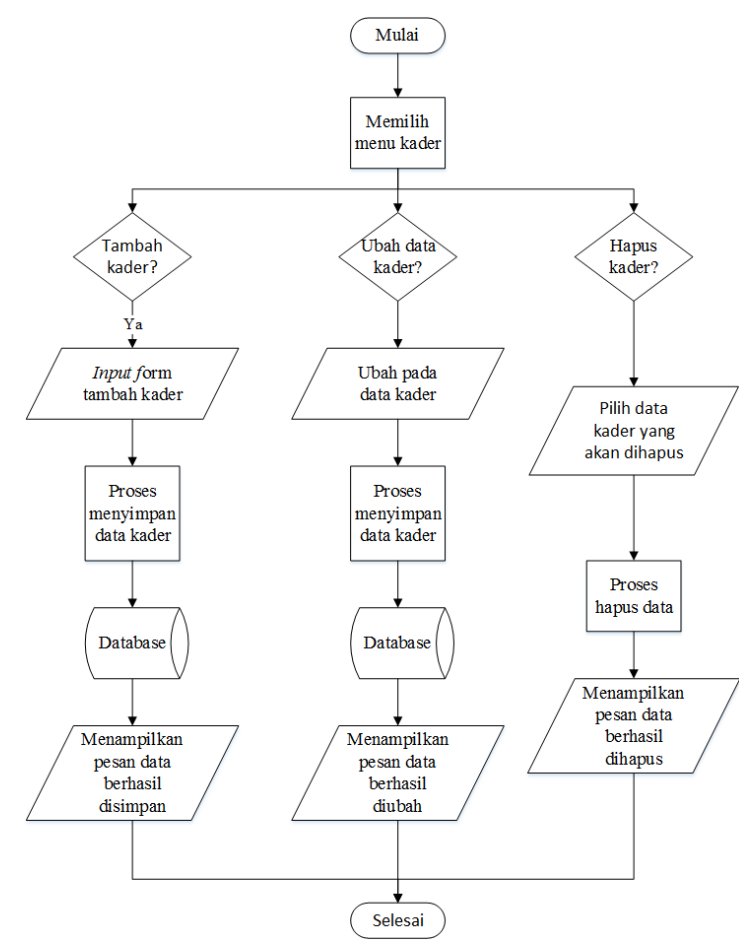

Gambar 6. Flowchart untuk mengelola kader

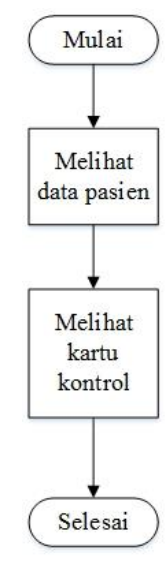

Gambar 7. Flowchart kartu kontrol

Flowchart kartu kontrol pada Gambar 7 menggambarkan bagan alur proses untuk melihat aktivitas pengobatan pasien saat menu data pasien dijalankan. Gambar 8 merupakan proses untuk mendaftar sebagai admin. Proses registrasi admin dilakukan oleh admin dengan mengisi data dalam form yang telah disediakan pada sistem. 


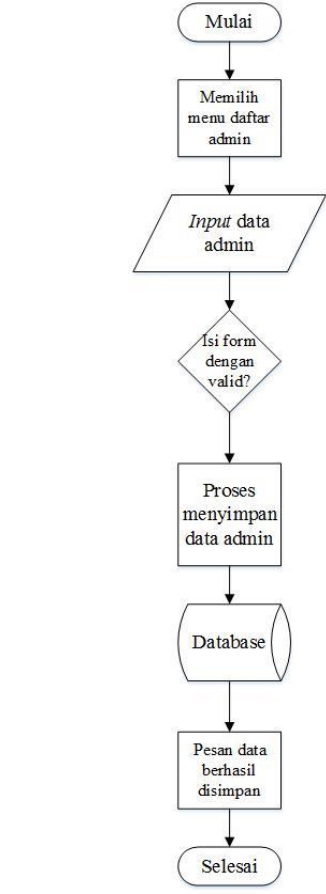

Gambar 8. Flowchart pendaftaran administrator

Gambar 9 adalah flowchart set kader untuk mengatur kader dalam pengawasan pasien saat menu kader dan set kader dijalankan. Gambar 10 merupakan proses untuk mengubah data kader untuk pengawasan pasien tertentu. Proses edit set kader dilakukan saat kader telah di-set oleh admin dengan mengisi data dalam form yang telah disediakan pada sistem.

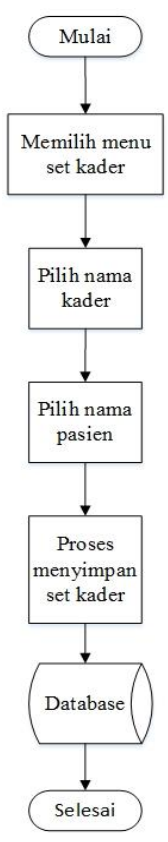

Gambar 9. Flowchart set kader

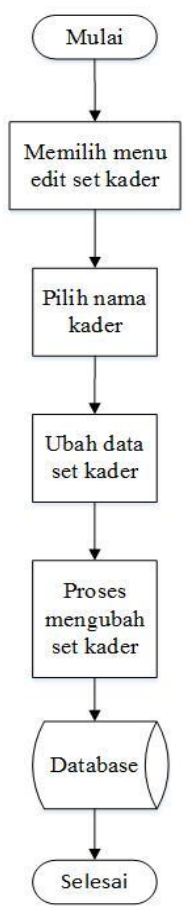

Gambar 10. Flowchart edit set kader

\subsection{Implementasi}

Pada tahapan ini merupakan tahap dimana sistem diterapkan menjadi sebuah aplikasi berbasis web. Perancangan kode program ini menggunakan bahasa scripting seperti PHP, CSS, JavaScript, dan jQuery. Penulis menjalankan aplikasi mulai dari menggunakan server localhost hingga menggunakan hosting melalui web hosting.

\subsection{Pengujian}

Tahap selanjutnya dalam penelitian ini adalah pengujian sistem. Tahapan ini bertujuan untuk mengevaluasi keunggulan dan kelebihan dari sistem yang telah dibuat serta menilai apakah sistem yang dirancang telah sesuai dengan yang diharapkan oleh pengguna. Setelah itu, penulis memberikan kuesioner yang dibagikan kepada petugas TB Care. Lalu, penulis menganalisis hasil kuesioner tersebut menggunakan teori User Experience Questionnaire (UEQ) (Schrepp 2015).

\section{Hasil dan Analisis}

Hasil dari penelitian ini berupa sebuah sistem monitoring dan controlling pasien TB berbasis web yang responsif. Beberapa tampilan 
dari sistem ini ditunjukkan pada Gambar 11, Gambar 12, Gambar 13, Gambar 14, Gambar 15, Gambar 16, dan Gambar 17.

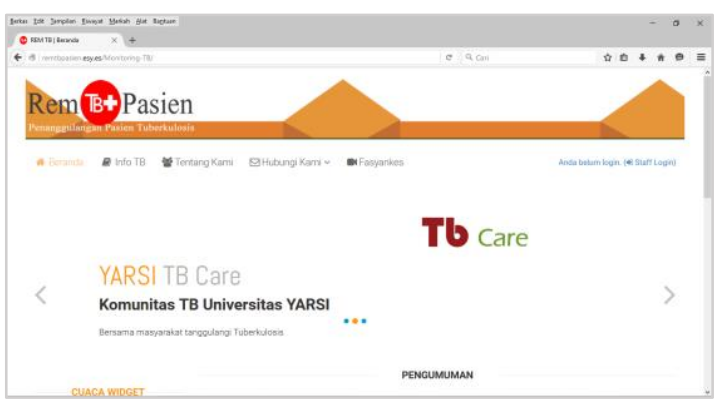

Gambar 11. Tampilan halaman utama pengguna tamu

Gambar 11 merupakan halaman utama tamu dimana pengguna tamu dapat mengakses menumenu yaitu: beranda, info TB, tentang kami, hubungi kami dan fasyankes. Halaman ini ditampilkan pada saat pengguna pertama kali mengakses sistem ini.

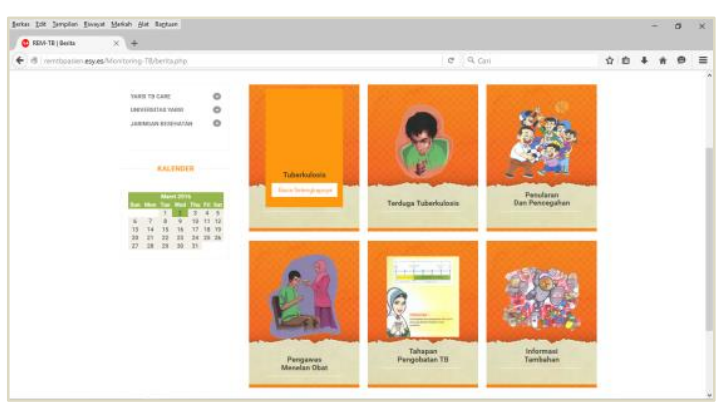

Gambar 12. Tampilan halaman info TB

Gambar 12, merupakan halaman kategori informasi seputar TB yang terdiri dari enam kategori yaitu Informasi Tuberkulosis, Terduga Tuberkulosis, Penularan dan Pencegahan, Pengawas Menelan Obat, Tahapan Pengobatan, dan Informasi Tambahan. Setiap kategori terdiri dari isi berita yang telah di-input oleh administrator.

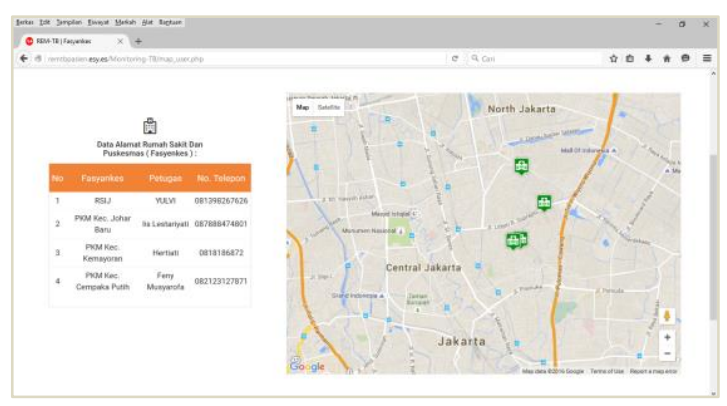

Gambar 13. Tampilan halaman fasyankes
Gambar 13 merupakan halaman untuk melihat peta lokasi penyebaran fasyankes yang berada di Jakarta Pusat, sehingga pengguna dapat mengetahui lokasi fasyankes di wilayah tersebut.

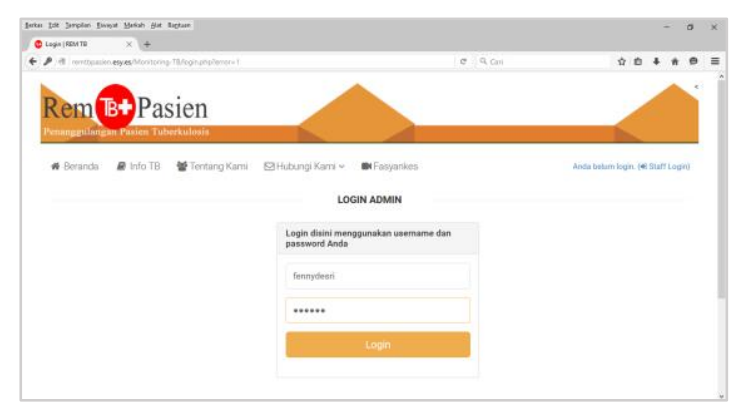

Gambar 14. Tampilan halaman login administrator

Gambar 14 merupakan tampilan form login sebagai pengguna admin dengan memasukkan username dan password yang valid untuk dapat mengakses halaman khusus administrator.

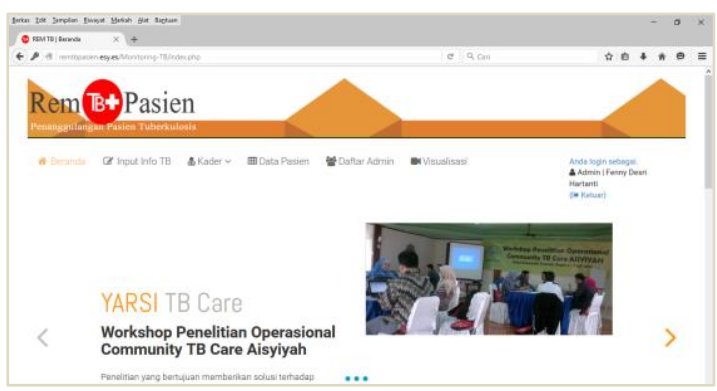

Gambar 15. Tampilan halaman utama administrator

Gambar 15 merupakan tampilan halaman utama administrator. Status sebagai administrator dan nama lengkap administrator akan muncul di pojok kanan atas setelah berhasil login ke sistem. Pada halaman ini, admin dapat mengakses menumenu yaitu: beranda, input info TB, kader (data kader, set kader, dan edit set kader), data pasien, daftar admin, dan visualisasi.

Gambar 16 adalah form untuk memasukkan berita terkait TB yang dapat diakses oleh admin. Informasi yang dimasukkan berisi judul berita, tanggal berita, kategori berita, isi berita, dan gambar pendukung berita. 


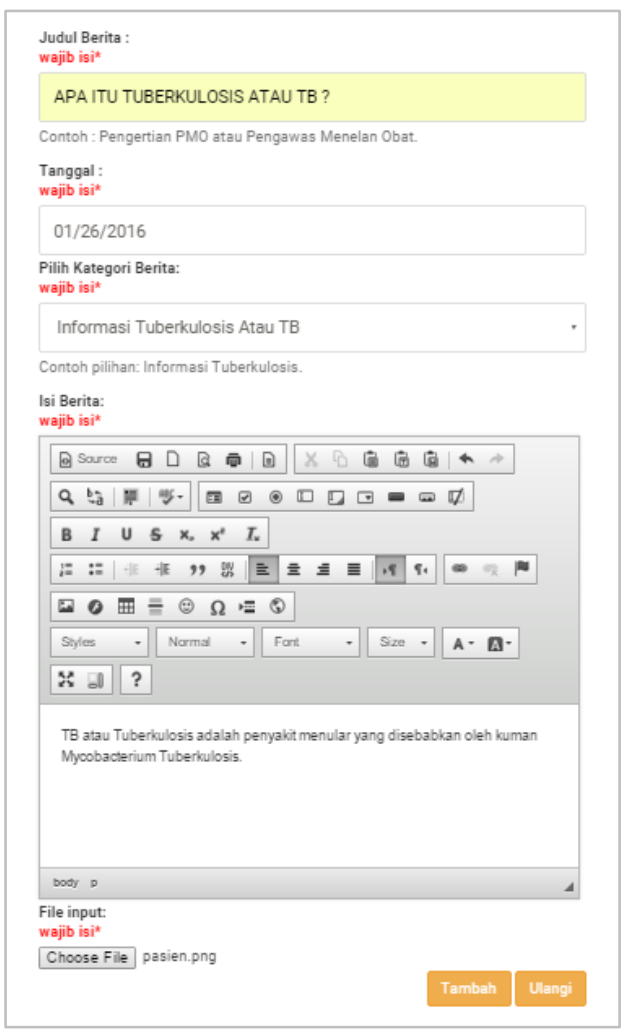

Gambar 16. Tampilan halaman input berita

Gambar 17 merupakan halaman yang digunakan untuk mengelola data kader seperti menambahkan, mengubah, dan menghapus data kader.

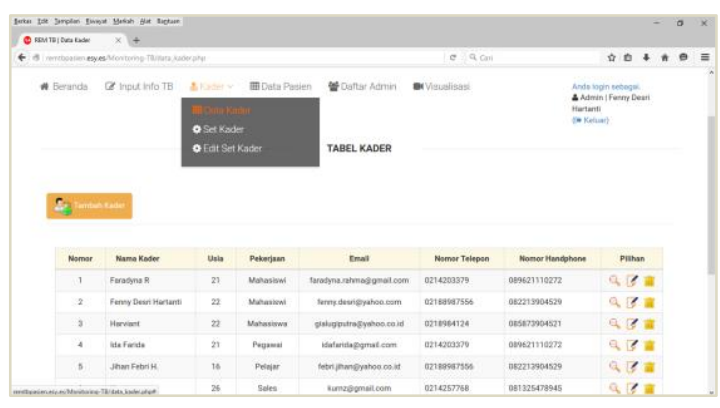

Gambar 17. Tampilan halaman kelola kader

Setelah sistem dibuat, dilakukan tahap pengujian untuk menilai dan mengevaluasi sistem, apakah sistem sudah layak digunakan. Pengujian dilakukan menggunakan teknik analisis User Experience Questionnire (UEQ) versi Indonesia.

Pengujian ini dilakukan dengan membagikan kuesioner kepada 3 orang responden yaitu petugas TB Care yang berlokasi di Jakarta Pusat. Pengujian dilakukan selama 2 hari, pada tanggal 16 - 17 Februari 2016. Kuesioner UEQ terdiri dari 26 pertanyaan.

Tabel 4 menunjukkan nilai dari setiap skala
UEQ yang diperoleh pada tahap pengujian. Skala efisiensi dan stimulasi mendapatkan nilai tertinggi di antara 6 skala yaitu 2,583. Urutan berikutnya adalah skala ketepatan yaitu 2,333. Kategori skala daya tarik, kejelasan, dan kebaruan mendapatkan nilai yang sama dan menempati urutan nilai terakhir yaitu 2,167 .

Tabel 4 Nilai skala UEQ

\begin{tabular}{|l|c|}
\hline \multicolumn{2}{|c|}{ Scales } \\
\hline Daya tarik & 仓 2.167 \\
\hline Kejelasan & 仓 2.167 \\
\hline Efisiensi & 仓 2.583 \\
\hline Ketepatan & 仓 2.333 \\
\hline Stimulasi & 仓 2.583 \\
\hline Kebaruan & 仓 2.167 \\
\hline
\end{tabular}

Hasil pada Tabel 4 dibandingkan terhadap benchmark data set menggunakan benchmark graph UEQ Indonesia. Data yang digunakan sebagai benchmark pada UEQ adalah 4818 orang dari 163 kajian berbagai produk (Schrepp 2015) seperti perangkat lunak bisnis, halaman situs, situs belanja, jaringan sosial. Gambar 18 menunjukkan grafik benchmark UEQ dari hasil pengujian sistem dimana skala daya tarik, kejelasan, efisiensi, ketepatan, stimulasi, dan kebaruan mendapatkan nilai excellent (sangat baik).

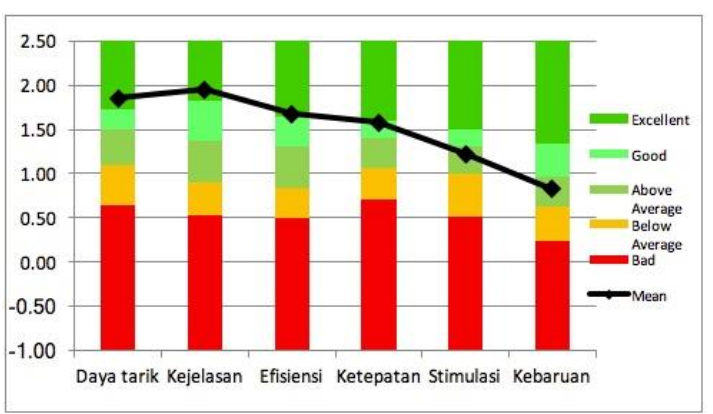

Gambar 18 Grafik benchmark sistem

\section{Kesimpulan}

Penelitian ini menghasilkan sebuah sistem berbasis web yang membantu petugas TB Care dalam mendata dan mengelola pasien tuberkulosis serta mengelola data kader, memantau pengobatan pasien TB dengan menghasilkan laporan-laporan aktivitas pengobatan dan jadwal minum obat serta periksa dahak pasien TB, dan memvisualisasikan data pasien berupa grafik. Pengujian sistem menggunakan User Experience Questionnire (UEQ) yang menunjukkan bahwa nilai skala daya tarik, kejelasan, efisiensi, ketepatan, stimulasi, dan kebaruan sistem sangat baik. 


\section{Referensi}

Asri, S D A 2014, 'Masalah Tuberkulosis Resisten Obat', $C D K-215$, vol. 41, no. 4, pp. 247-249, viewed $26 \quad$ Oktober 2015, http://www.kalbemed.com/Portals/6/05_215C ME_Masalah\%20Tuberkulosis\%20Resisten\% 200bat.pdf.

Harjana, D 2013, 'Gejala TB, Penyebab, dan Cara Pengobatan TB'.

Kemenkes RI 2011, Terobosan Menuju Akses Universal: Strategi Pengendalian TB di Indonesia 2010-2014, Jakarta:Kementerian Kesehatan RI Direktorat Jenderal Pengendalian Penyakit dan Penyehatan Lingkungan, viewed 26 Oktober 2015, http://www.searo.who.int/indonesia/topics/tb/s tranas_tb-2010-2014.pdf.
Kemenkes RI 2014, Pedoman Nasional Pengendalian Tuberkulosis, Jakarta:Kementerian Kesehatan RI Direktorat Jenderal Pengendalian Penyakit dan Penyehatan Lingkungan, viewed 26 Oktober 2015, http://www.tbindonesia.or.id/2015/02/11/bukubpnptb-2014/.

Schrepp, M. 2015, UEQ - User Experience Questionnaire, viewed 26 Oktober 2015, http://www.ueq-online.org/.

World Health Organization 2015, Global Tuberculosis Report, $20^{\text {th }}$ Edition, viewed 26 Oktober

2015 , http://apps.who.int/medicinedocs/documents/s 22199en/s22199en.pdf. 